\title{
Article
}

\section{Seed biologists beware: end-of-trial estimation of initial viabil- ity may be error-prone due to unexpected seed death during the experiment}

\author{
Byron B. Lamont ${ }^{* 1}$, Rosemary J. Newton ${ }^{2}$, Pablo Gomez-Barreiro² and Tianhua He ${ }^{1}$
}

\author{
${ }^{1}$ Department of Molecular and Life Sciences (Ecology Section), CurtinUniversity, PO Box U1987, Perth, WA \\ 6845, Australia; B.Lamont@curtin.edu.au \\ 2 Conservation Directorate, Royal Botanic Gardens Kew, Wakehurst Place, Ardingly, West Sussex, RH17 6TN, \\ United Kingdom; r.newton@kew.org \\ ${ }^{3}$ Conservation Directorate, Royal Botanic Gardens Kew, Wakehurst Place, Ardingly, West Sussex, RH17 6TN, \\ United Kingdom; P.Gomez@kew.org \\ ${ }^{4}$ Department of Molecular and Life Sciences (Ecology Section), Curtin University, PO Box U1987, Perth, WA \\ 6845, Australia; Tianhua.He@curtin.edu.au \\ * Correspondence: Correspondence B.Lamont@curtin.edu.au
}

\begin{abstract}
Seed viability is routinely measured on seeds that fail to germinate at the end of an experiment. Together with the number of germinants, this is used to estimate viability of the seeds at start of the experiment (i.e., initial viability) and provides the comparative basis on which germination success is determined. We used this standard procedure on 40 Leucadendron species subjected to oscillating temperatures, heat and/or smoke pre-treatments to examine the extent to which they raised germination levels above that of the untreated controls. 16 species showed significantly different levels of estimated initial seed viability between treatments when they should have been unaffected. Loss of viability during the trial was an order of magnitude greater than annual loss during cold storage, which was usually negligible. Lowest levels of estimated initial viability occurred among the poorly germinating controls and confirmed that the heat and smoke treatments had little effect on viability. Species with soil-stored seeds were more vulnerable to this artefact than those with plant-stored seeds. We caution against the routine use of end-of-trial germination and viability of ungerminated seeds as an estimate of initial viability in determining germination success of various treatments. The preference is for estimates of initial viability to be undertaken on a separate sample of seeds in association with the trial.
\end{abstract}

Keywords: germination; Leucadendron; seed storage; seed viability estimation; viability loss

\section{Introduction}

Determining initial viability is a vital part of testing the germination potential and requirements of seeds, since germination success can only be compared against seeds that were capable of germinating in the first place. Researchers usually gauge seed viability at the start of a trial/experiment (initial viability) on the condition of seeds remaining at the end of the trial plus those that had germinated: a representative sample of 13 of such studies are described in Table 1. Thus, estimated initial viability [1](Gosling (2003) is given by: (viable seeds present at end of trial + germinants)/(total seeds in trial). The results are then corrected for viability: (seeds germinated)/(total seeds in trial $\times$ initial viability). This economizes on the number of seeds needed for the trial as it is not necessary to 'waste' seeds by testing for viability on separate samples before the trial begins. This can be important when seeds are scarce if the species is rare, or seeds are difficult to collect or expensive to purchase. It also removes any time-lapse loss of viability between estimating viability before the trial begins and undertaking the trial itself. Further, it expedites the testing task as only ungerminated seeds need be examined for their viability. 
It also avoids the need to use a mean value obtained pre-trial to apply to all treatments that ignores sample effects on the viability of seeds used as 'actual' initial viability of the seeds used in each replicate can be estimated.

We used this standard procedure in a study of the fire-related germination requirements of 40 representative species in Leucadendron, an abundant shrub genus of Proteaceae in the fire-prone Cape of South Africa [2\}(Williams 1972, ([3]Tonnabel et al. 2018). On collating the data we noted what appeared to be differences in the calculated levels of initial viability between treatments for some species, especially among the untreated controls, when they should have been the same. This indicated that there might be an unanticipated treatment effect on the viability of seeds remaining at the end of the trial, biasing their use for estimating initial viability. We checked the literature and found that Hay and Probert [4](2013) had already warned that seeds kept for prolonged periods under (suboptimal) experimental conditions can die though they did not present supporting data. Inspection of 13 representative papers that used the end-of-trial approach in Table 1 revealed several with variable post-trial estimates of initial viability that were not commented on by the authors [5](Clarke et al. 2000, [6]Hall et al. 2017, [7]Gómez-González et al. 2017). That is, estimates of initial viability varied between treatments and, unexpectedly, were especially low among the untreated controls. As an example of the potential problem, our collation of data from Gómez-González et al. [7] highlights a case where estimates of viability for three species were anomalously low among the controls compared with the treatments (Figure 1).

Here, we compare the calculated initial seed viability of the 40 Leucadendron species under 4-5 treatments, and select out some to show how this varied with the levels of germination, seed storage type and duration of the trial, and compare the results against loss of viability during cold storage in the laboratory. We show that loss of viability may occur during the trial, especially among the control treatments with little germination, that will lead to erroneous estimates of germination success if this artefact is not recognized. We therefore warn against routine use of post-trial estimates of initial viability, especially if the trial is long-running. 
Table 1. Examples of studies that used assessment of seed viability and germination at the end of the experiment to estimate initial viability.

\begin{tabular}{|c|c|c|c|c|}
\hline Species tested & $\begin{array}{l}\text { Method of determining initial viability } \\
\text { end-of-experiment data }\end{array}$ & Experimental conditions & $\begin{array}{lr}\text { Differing } & \text { initial } \\
\text { viability } & \text { between } \\
\text { treatments } & \end{array}$ & Reference \\
\hline $\begin{array}{l}21 \text { woody native species of Chilean } \\
\text { matorral }\end{array}$ & $\begin{array}{l}\text { Viability calculated as: those germinated during the } \\
\text { monitoring period plus non-germinated seeds identified as } \\
\text { viable by tetrazolium test }\end{array}$ & $\begin{array}{l}\text { Moist absorbent paper in petri dishes at } 20 / 10^{\circ} \mathrm{C} \\
\text { with } 12 / 12 \mathrm{~h} \text { light/dark for } 36 \mathrm{~d}\end{array}$ & $\begin{array}{l}\text { Yes (3 species), data } \\
\text { not adjusted for } \\
\text { viability }\end{array}$ & $\begin{array}{l}\text { Gómez-Gonz } \\
\text { ález et al. [7] }\end{array}$ \\
\hline $\begin{array}{l}13 \text { native and one introduced species } \\
\text { (Acacia saligna) of South African fynbos }\end{array}$ & $\begin{array}{l}\text { Viability determined as the sum of germinated seeds and } \\
\text { seeds appearing fresh on dissection of ungerminated seeds }\end{array}$ & $\begin{array}{l}1 \% \text { water agar at } 10 / 20^{\circ} \mathrm{C} \text { with a } 12 \mathrm{~h} \text { light and dark } \\
\text { cycle for } 91 \mathrm{~d}\end{array}$ & $\begin{array}{l}\text { Yes (at least } \\
\text { species) }\end{array}$ & Hall et al. [6] \\
\hline $\begin{array}{l}65 \text { species commonly occurring on New } \\
\text { England tableland (NSW Australia) }\end{array}$ & $\begin{array}{l}\text { Seeds that did not germinate, but looked viable, were } \\
\text { analysed using tetrazolium test. Viability based on treatment } \\
\text { with highest germination plus any seeds that remained } \\
\text { dormant but viable }\end{array}$ & $\begin{array}{l}\text { Moist pad in dish at } 25 / 15^{\circ} \mathrm{C} \text { with a } 12 / 12 \mathrm{~h} \\
\text { light/dark for } 28 \text { or } 56 \mathrm{~d}\end{array}$ & $\begin{array}{l}\text { Probably (as used } \\
\text { highest viability levels } \\
\text { between treatments) }\end{array}$ & $\begin{array}{l}\text { Clarke et al. } \\
{[5]}\end{array}$ \\
\hline $\begin{array}{l}\text { Asterolasia buxifolia, riparian habitat of } \\
\text { SE Australia }\end{array}$ & $\begin{array}{l}\text { Embryo dissected from } 20 \text { seeds that did not germinate and } \\
\text { viability confirmed if embryo and endosperm intact }\end{array}$ & $\begin{array}{l}\text { Moist filter paper in petri dishes at } 11 / 3^{\circ} \mathrm{C} \text { with } \\
12 / 12 \mathrm{~h} \text { in light/dark for } 77 \mathrm{~d}\end{array}$ & $\begin{array}{l}\text { Data not adjusted for } \\
\text { viability* }\end{array}$ & $\begin{array}{l}\text { Collette and } \\
\text { Ooi [8] }\end{array}$ \\
\hline $\begin{array}{l}10 \text { native species of Mediterranean } \\
\text { Basin maquis }\end{array}$ & $\begin{array}{l}\text { Embryo dissected from } 20 \text { seeds that did not germinate and } \\
\text { viability confirmed if embryo intact }\end{array}$ & $\begin{array}{l}\text { Soil in trays in glass house for } 84 \mathrm{~d} \text { over } \\
\text { winter-spring, Perth, Australia }\end{array}$ & $\begin{array}{l}\text { Data not adjusted for } \\
\text { viability }\end{array}$ & Crosti et al. \\
\hline $\begin{array}{l}46 \text { legumes species of tropical savanna, } \\
\text { Brazil }\end{array}$ & $\begin{array}{l}\text { Initial viability equals the sum of germinated and dormant } \\
\text { seeds in control }\end{array}$ & $\begin{array}{l}\mathrm{r} \text { in petri dishes at } 27^{\circ} \mathrm{C} \text { with } 12 / 12 \\
8 \mathrm{~d}\end{array}$ & $\begin{array}{l}\text { No data at treatment } \\
\text { level }\end{array}$ & Daibes et al. \\
\hline $\begin{array}{l}13 \text { species of West African savanna } \\
\text { woodland }\end{array}$ & $\begin{array}{l}\text { Cut test - condition of embryo, } \\
\text { conducted on ungerminated seeds post-trial }\end{array}$ & Moist filter paper in bell jars at $25^{\circ} \mathrm{C}$ light for $30 \mathrm{~d}$ & $\begin{array}{l}\text { No data at treatment } \\
\text { level }\end{array}$ & $\begin{array}{l}\text { Dayamba et } \\
\text { al. [11] }\end{array}$ \\
\hline 9 species in Brazilian Cerrado & Cut test for post-treatment seed viability & at $25^{\circ} \mathrm{C}$ with a $12 / 12$ & No & $\begin{array}{l}\text { Fernandes et } \\
\text { al. [12] }\end{array}$ \\
\hline $\begin{array}{l}7 \text { native perennial forb species of } \\
\text { grasslands and woodlands of SE } \\
\text { Australia }\end{array}$ & $\begin{array}{l}\text { Cut test - condition of embryo on ungerminated seeds } \\
\text { post-trial }\end{array}$ & $\begin{array}{l}1 \% \text { water agar at } 25 / 15^{\circ} \mathrm{C} \text { with a } 12 / 12 \mathrm{~h} \text { light/dark } \\
\text { for } 56 \mathrm{~d}\end{array}$ & $\begin{array}{l}\text { No data at treatment } \\
\text { level }\end{array}$ & $\begin{array}{l}\text { Hodges et al. } \\
{[13]}\end{array}$ \\
\hline $\begin{array}{l}2 \text { alien and } 2 \text { indigenous legume } \\
\text { species in S African fynbos }\end{array}$ & $\begin{array}{l}\text { Germination level of scarified seeds conducted at same time } \\
\text { as other treatments }\end{array}$ & $\begin{array}{l}\text { in petri dishes at } 20^{\circ} \mathrm{C} \text { with } \\
\text { or } 60 \mathrm{~d}\end{array}$ & $\begin{array}{l}\text { No data at treatment } \\
\text { level }\end{array}$ & $\begin{array}{l}\text { Jeffery et al. } \\
{[14]}\end{array}$ \\
\hline $\begin{array}{l}3 \text { species of Acronychia in E Australian } \\
\text { rainforest }\end{array}$ & $\begin{array}{l}\text { Ungerminated seeds checked for firmness by pressing seed } \\
\text { with forceps. Then firm seeds checked for viability via cut } \\
\text { test }\end{array}$ & $\begin{array}{l}0.8 \% \text { water agar in petri dishes at } 25 / 10^{\circ} \mathrm{C} \text { with a } \\
12 / 12 \mathrm{~h} \text { light/dark for } 28 \mathrm{~d}\end{array}$ & $\begin{array}{l}\text { No data at treatment } \\
\text { level }\end{array}$ & $\begin{array}{l}\text { Liyanage et } \\
\text { al. [15] }\end{array}$ \\
\hline $\begin{array}{l}9 \text { herbaceous species in Brazilian } \\
\text { grassland }\end{array}$ & Tetrazolium test on ungerminated seeds & $\begin{array}{l}\text { Moist filter paper in petri dishes at } 20^{\circ} \mathrm{C} \text { or } 25^{\circ} \mathrm{C} \text { at } \\
16 / 8 \mathrm{~h} \text { in light/dark for } 21 \mathrm{~d}\end{array}$ & $\begin{array}{l}\text { No data at treatment } \\
\text { level }\end{array}$ & $\begin{array}{l}\text { Overbeck et } \\
\text { al. [16] }\end{array}$ \\
\hline Brassica napus & $\begin{array}{l}\text { Cotyledon condition of ungerminated seeds post-trial. } \\
\text { Necrotic cotyledons }=\text { nonviable, yellow-milky cotyledons = } \\
\text { viable }\end{array}$ & $\begin{array}{l}\text { Moist filter paper in petri dishes at } 20^{\circ} \mathrm{C} \text { in dark for } \\
35 \mathrm{~d}\end{array}$ & No & $\begin{array}{l}\text { Shayanfar et } \\
\text { al. [17] }\end{array}$ \\
\hline
\end{tabular}

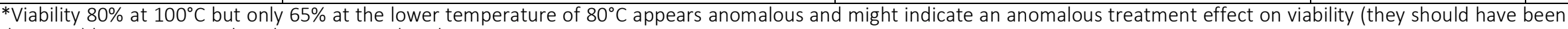
the same) but no statistical analyses were undertaken 


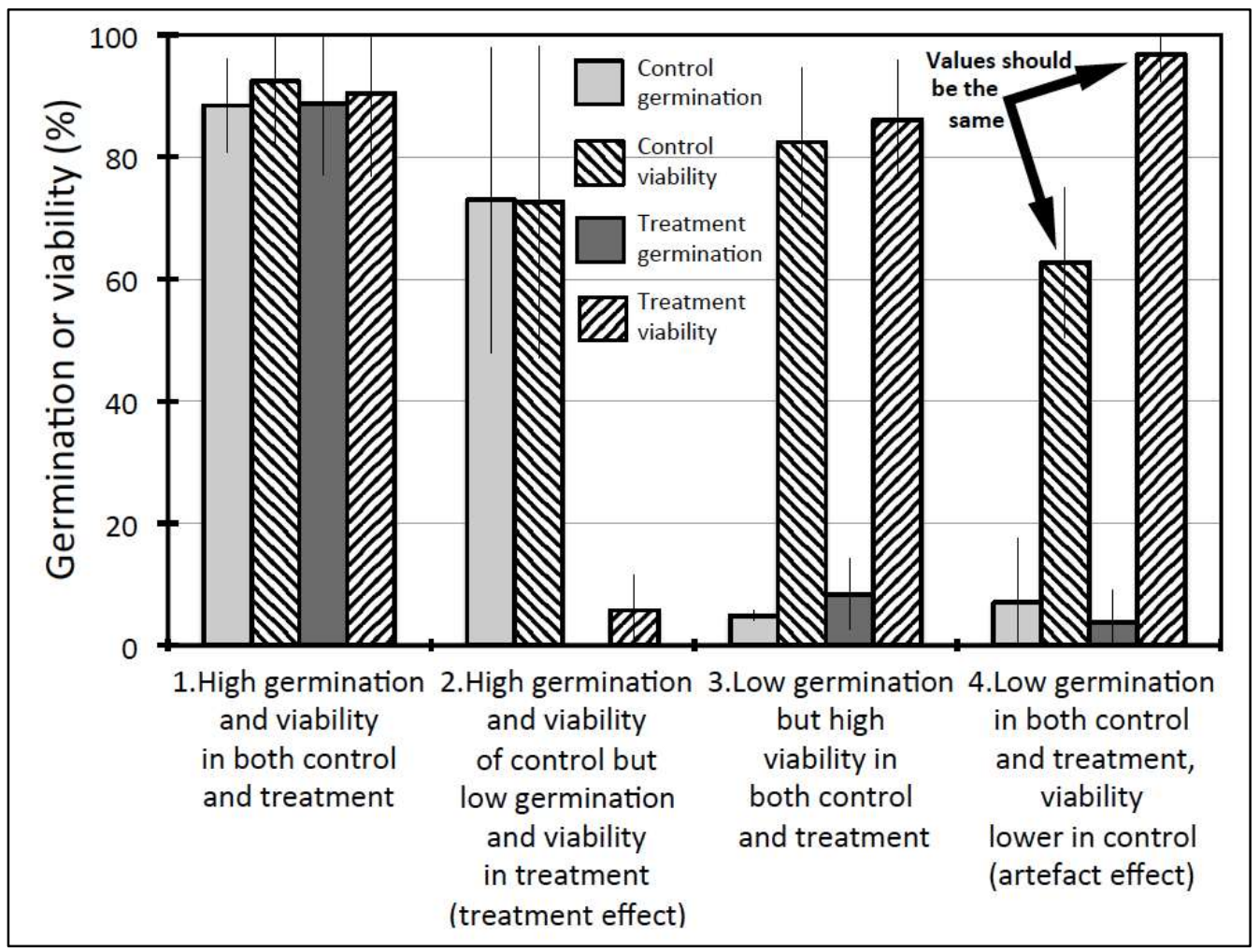

Figure 1. Example of anomalous reduction in viability of some controls.

Data collated from Gómez-González et al. [7] divided into four categories varying in germination and viability determined at the end of the trial with three species in each category. Results are means $\pm 95 \%$ CIs. Note the last category where viability of the control is on average $36 \%$ less than the heat treatment $\left(100^{\circ} \mathrm{C}\right.$ for $\left.3 \mathrm{~min}\right)$, that must be an artefact of the experimental method as, at best, viability of both should be the same (categories 1 and 2) and, at worst, the treated seeds would have lower viability at the end of the trial than the controls if the heat was excessive as in category 2 (not the reverse as here). Note that the unexpected control effect occurs among species with little germination of the controls but it is not unique in that respect (for example, see category 3 that also has low \% germination but without reduction in viability).

\section{Results}

Table A1 summarizes seed viability differences among 40 Leucadendron species as determined by the 'cut' test. The tests of viability carried out during 0-10 years of cold storage showed that there was zero effect on viability at the various intervals for 12 of the 17 species assessed, with a mean loss of $0.43 \%$ pa (Table 2, Figure 2). There was no trend in viability loss with time and none of the five species with non-zero values was significantly $>0$. There were differential effects between the 4 treatments on estimates of viability at the start of the trial for 16 of the 40 species (Tables 2,A). The maximum difference in viability estimates between any two treatments within a species ranged from a mean of $1.2 \%$ (non-significant) to $35.8 \%$, with a mean difference of $6.4 \%$, and $8.7 \%$ for the 17 species in common with those in cold storage assessed (Table A1, Figure 2). Thus, seeds were likely to lose $20 \times$ more viability over the $2-5$ months of the trial than during 12 months in cold storage. This can be compared with the $1.5 \%$ maximum difference in filled seeds between any two treatments that was a random effect for all but two species for which the difference was significant. Thus, the difference in viability for $14(16-2)$ species between treatments that developed during the trial is a non-random effect. 
Table 2. Loss of seed viability among 17 Leucadendron species air-dried and stored at $-20^{\circ} \mathrm{C}$ for one to 120 months, and maximum differences in estimated initial viability (on embryo-filled seed basis) and embryo-filled (on total seed basis) between $4-5$ treatments designed to identify conditions that break dormancy among 40 Leucadendron species distinguished according to whether they store seeds on the plant or in the soil. Mann-Whitney tests of A to D to put each species into its appropriate category (Table A1), followed by contingency table analyses between categories.

\begin{tabular}{|c|c|c|c|c|c|}
\hline \multirow{2}{*}{$\begin{array}{c}\text { Where stored } \\
\text { Viability changes/differences }\end{array}$} & \multicolumn{2}{|c|}{ On plant } & \multicolumn{2}{|c|}{ In soil } & \multirow{2}{*}{$\frac{\text { Significance }}{P}$} \\
\hline & Yes & No & Yes & No & \\
\hline A. Loss of viability during cold storage $(\% \mathrm{pa})$ & 0 & $9(7$ at 0$)$ & 0 & $8(5$ at 0$)$ & $>0.05$ \\
\hline $\begin{array}{l}\text { B. Significant maximum differences in seed viability } \\
\text { between } 4 \text { treatments }\end{array}$ & 10 & 21 & 6 & 3 & $<0.05$ \\
\hline $\begin{array}{l}\text { C. Significant maximum differences in filled seeds } \\
\text { between } 4 \text { treatments }\end{array}$ & 1 & 30 & 1 & 8 & $>0.05$ \\
\hline Comparison & & B & & $\mathrm{C}$ & \\
\hline Significant differences & Yes & No & Yes & No & \\
\hline D. Significant maximum differences & 16 & 24 & 2 & $38(12$ at 0$)$ & $<0.05$ \\
\hline
\end{tabular}

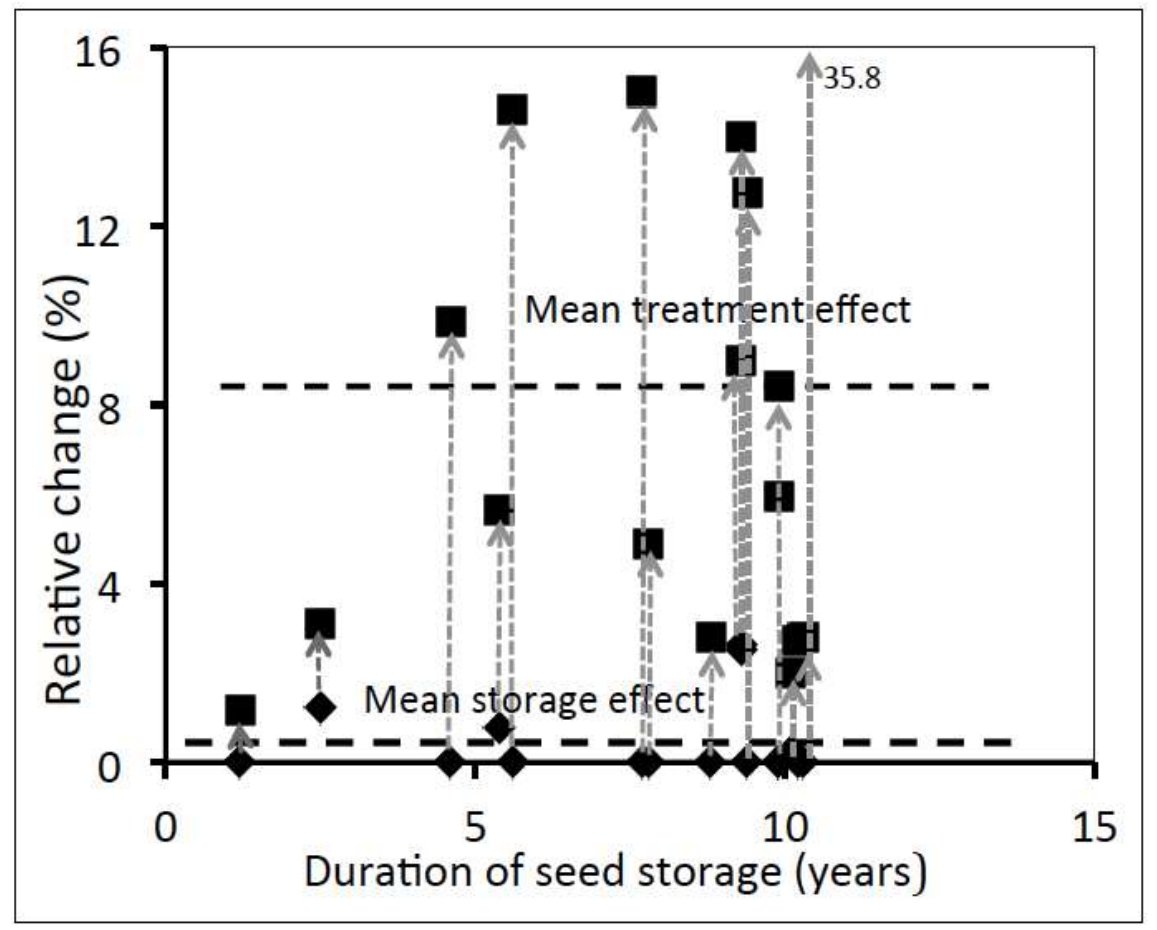

Figure 2. Comparative loss of viability during cold storage compared with during the experiment.

Loss of binomial mean seed viability (relative change) among 17 Leucadendron species (data incomplete for the remaining 23 species, Table A1, so omitted) during cold storage varying in duration as shown $(\diamond$, loss rate per year of storage, \%) (viability remained at $100 \%$ for 11 species) compared with the same source of seeds subjected to $4-5$ treatments (Table A1) over 2-5 months (ם), with the greatest difference in binomial means between treatments on viability plotted. The loss rate for stored seeds was assessed on 2-3 viability tests for the period indicated.

The ten species selected showed large differences in the relationship between \% germination and \% initial viability (Figure 3). The logarithmic slope varied from 0.0125 (negligible relationship between germination and viability) to 0.1612 (rapid decline in viability as germination declined). A linear slope was applied to L. foedum as all seeds that did not germinate were nonviable $\left(R^{2}=1.000\right)$. From these curves, the viability data were extrapolated back to the diagonal in Figure 3, i.e., where viability and germination levels 
coincide and represent the maximum (true?) initial viability of that batch of seeds, ranging from $100 \%$ ( six species) to $66 \%$ (L. corymbosum) (Table 3). At a nominated germination level of $20 \%$, estimated initial viability fell from a minimum of $95.7 \%$ (negligible effect of the treatment on viability, despite the low germination) to a maximum of $20.0 \%$ (viability is a function of germination level on grounds that seeds which did not germinate lost viability). The net loss in viability from treatments associated with $60 \%$ to $20 \%$ germination ranged from $2.0 \%$ (negligible effect) to $40 \%$ (total dependence) (Table 3).
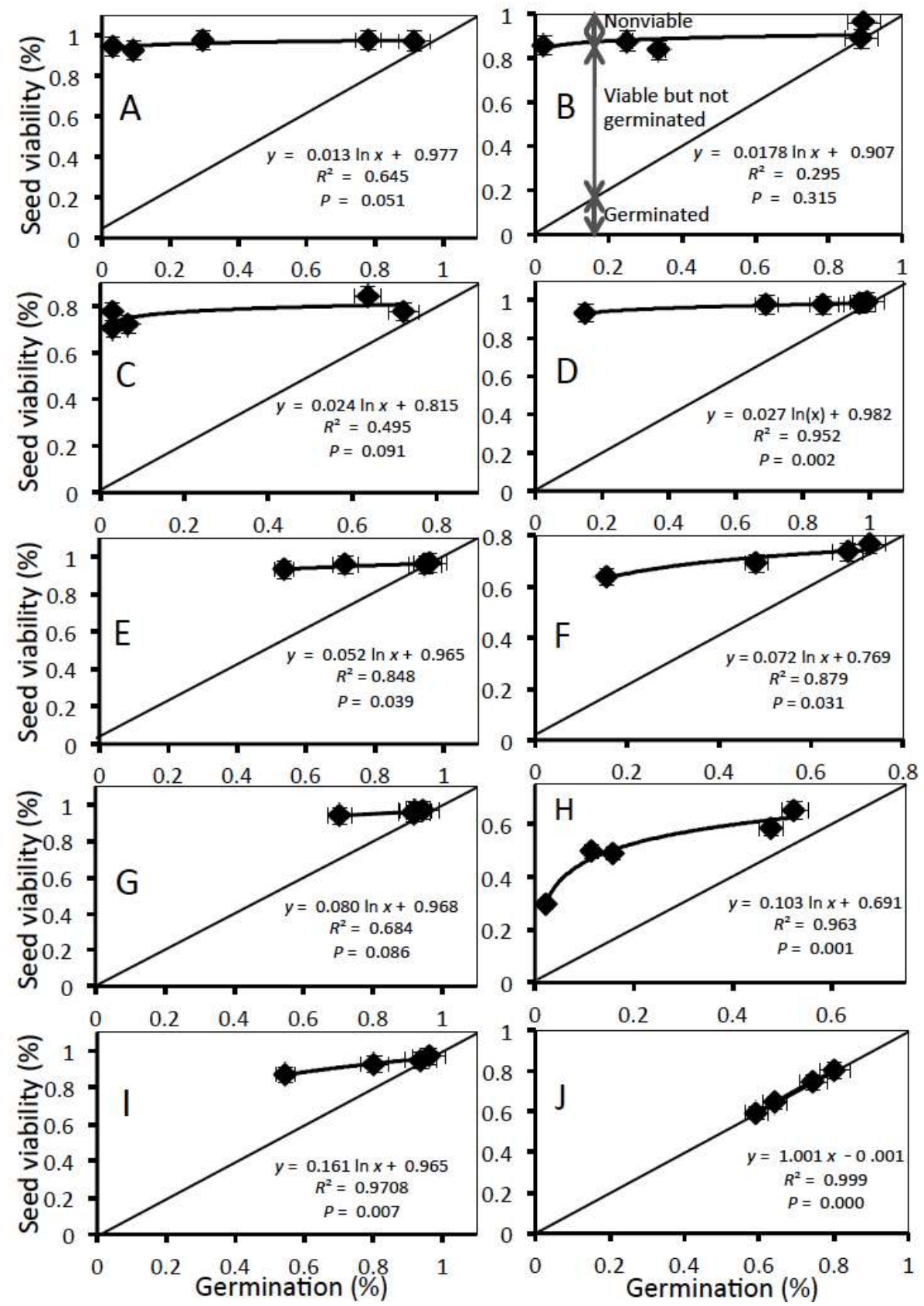

Figure 3. Level of germination (binomial mean \pm binomial SE) for 10 Leucadendron species in $4-5$ treatments as it correlates with initial seed viability (binomial mean \pm binomial SE) estimated at the end of the trial. Species listed from those whose viability was least to most affected by the treatments according to the fitted slopes. The trend lines are the logarithmic relationships between the data, with the associated equation, $R^{2}$ and $P$ values given. The diagonal is that position where all viable seeds germinate. The closer estimated viability is to the diagonal the greater it is a function of its germinability. Note that the lowest viability value for a given species is invariably the control (lowest germination). $\mathrm{A}=$ L. elimense, $\mathrm{B}=\mathrm{L}$. laxum, $\mathrm{C}=$ L. brunioides, $\mathrm{D}=$ L. chamalaea, $\mathrm{E}=$ L. galpinii, $\mathrm{F}=$ L. thymifolium, $\mathrm{G}=$ L. dregei, $\mathrm{H}=$ L. corymbosum, $\mathrm{I}=$ L. modestum, $\mathrm{J}=$ L. foedum 
Table 3. Relationship between estimated binomial mean initial seed viability (\%) and germination (\%) for 10 Leucadendron species from logarithmic curve fits for $4-5$ treatments (except linear fit for L. foedum).

\begin{tabular}{cccc}
\hline $\begin{array}{c}\text { Leucadendron } \\
\text { species }\end{array}$ & $\begin{array}{c}\text { 'True' initial viability by } \\
\text { extrapolation to diagonal (Figure 3) }\end{array}$ & $\begin{array}{c}\text { Estimated initial viability at 20\% } \\
\text { germination }\end{array}$ & $\begin{array}{c}\text { Loss of viability as } \\
\text { germination falls from } \mathbf{6 0 \%} \text { to } \\
\mathbf{2 0 \%}\end{array}$ \\
\hline elimense & 98 & 95.7 & 2.0 \\
\hline laxum & 92 & 87.8 & 2.9 \\
\hline brunioides & 83 & 77.6 & 3.9 \\
\hline chamalaea & 100 & 93.9 & 4.3 \\
\hline galpinii & 98 & 88.1 & 8.3 \\
\hline thymifolium & 76 & 65.3 & 11.6 \\
\hline dregei & 99 & 83.9 & 12.8 \\
\hline corymbosum & 66 & 52.6 & 13.4 \\
\hline modestum & 99 & 70.6 & 25.9 \\
\hline foedum & 100 & 20.0 & 40.0 \\
\hline
\end{tabular}

As L. corymbosum showed the greatest difference in estimated initial viability between treatments (35.8\%) (Table A1, Figure 3), it was selected for in-depth comparison of four treatments each with five replicates for any relationship between germination failure and nonviability (Figure 4). This showed that, as germination levels decreased, seed viability decreased at a similar rate, with 5-6\% remaining alive but not germinating. If viability was unaffected by treatment effects on the level of germination then there would be a horizontal line running at a point equal to the 'actual' level of nonviability right of the diagonal line (nonviable seeds cannot germinate).

Duration of the trial for each replicate was compared between the treatments using the highest and lowest levels of estimated initial viability for each species. This period varied from 57 to 175 days with a mean of 131 days and the values were identical between the pairs of values for each species. Thus, there was no within-species effect on viability associated with duration of the trial. For four species with marked treatment effects on estimated viability, Figure 5 shows a linear relationship between duration of seeds in the treatment with increased loss of viability. Because of the lack of data for the 80-100-day period, the results are bimodal and do not clearly fit any unimodal relationship. Nevertheless, a linear trend can be detected, although the relationship only accounted for $12 \%$ of variation in the data. On average, $23 \%$ of seeds were nonviable if left in the treatment for 60 days and 39\% were nonviable if left for 140 days, so that duration of the treatment without germination had a small but significant effect on seed viability. This means species that were slower to germinate were more likely to lose viability than those that were faster to germinate (under the treatment for a shorter time). 


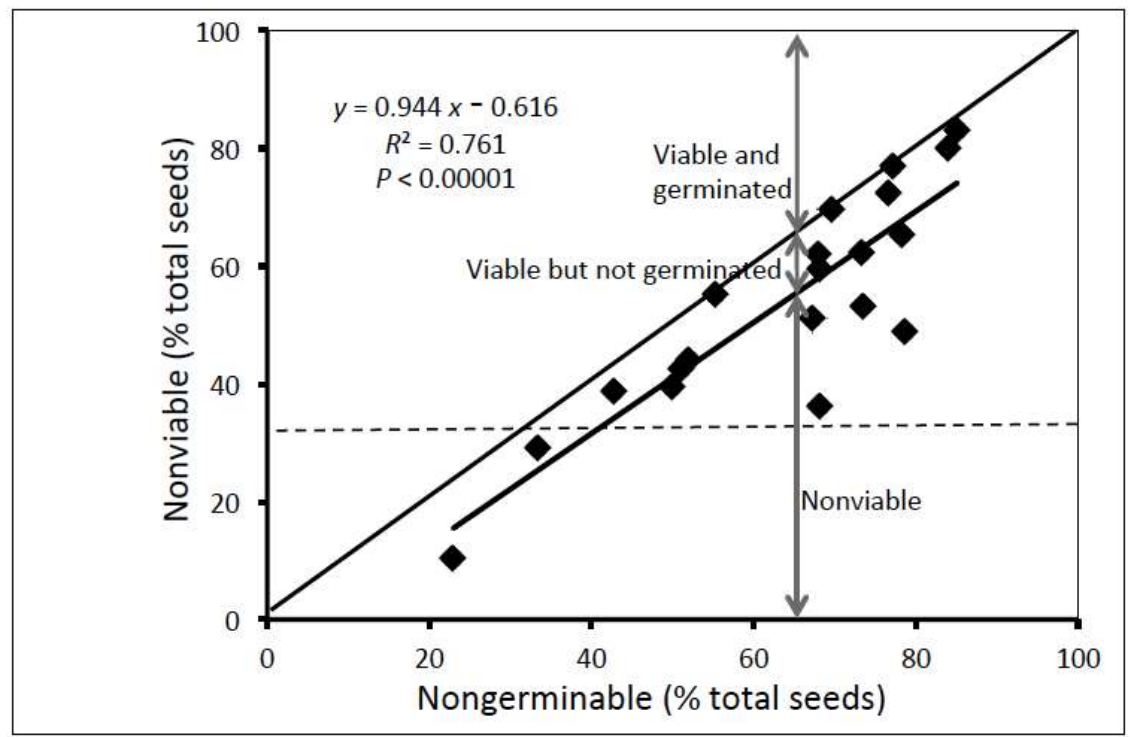

Figure 4. Estimated initial viability vs germinability of seeds of L. corymbosum.

Estimated initial viability vs germinability of seeds of L. corymbosum over four treatments each with five replicates, all plotted. If initial viability (V) was $66 \%$ (Table 2), then nonviability $(\mathrm{NV}=100-\mathrm{V}$, when $\mathrm{G}=0$ ) should follow the broken line at $34 \%$ as shown, independent of the level of subsequent germination $(\mathrm{G})$. The diagonal represents the situation where all seeds that do not germinate are not viable $(100-G=100-V)$. The fitted slope represents that fraction of nongerminable seeds that was nonviable as a treatment and/or replicate effect. This shows that, as germination decreased (left to right), estimated initial viability decreased (bottom to top) is parallel to the diagonal [when it should have remained constant at $66 \%$, as those seeds that do not germinate should remain viable: $\mathrm{NV}$ (constant) $=100-\mathrm{G} \downarrow-\mathrm{V}^{\uparrow}$ ], with a constant $5-6 \%$ remaining alive but not germinating.

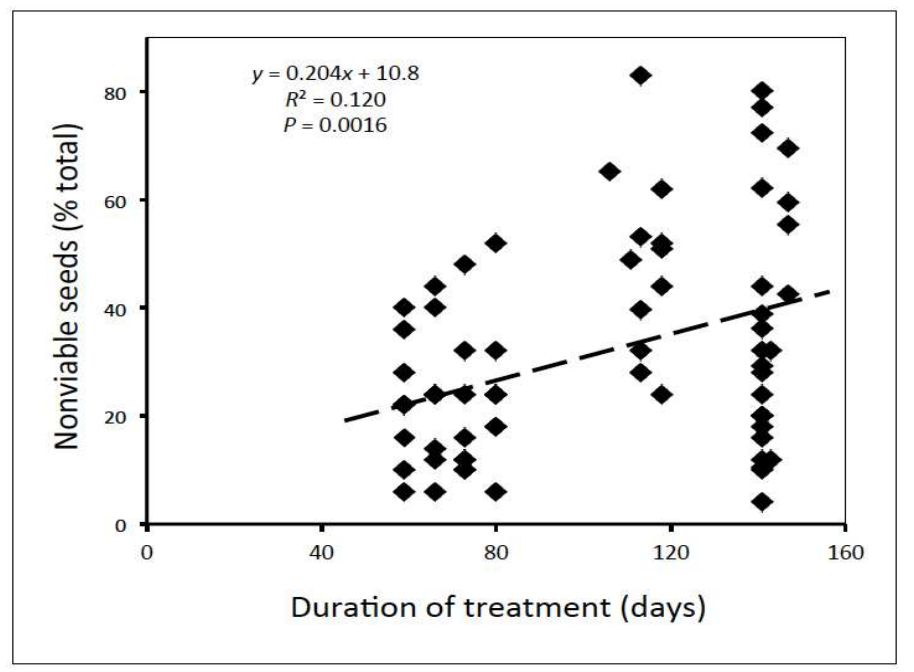

Figure 5. Nonviable seeds present at the end of the trial compared with duration of the trial.

Nonviable seeds present at the end of the trial compared with duration of the trial.for all replicates and treatments for four species that showed marked treatment effects on initial viability estimates (Table A1) and covered a wide range of treatment durations: L. corymbosum, L. foedum, L. loranthifolium and L. laureolum. The fitted line is broken to indicate that the data do not describe a normal curve and do not fit the assumptions of 
the model so it can only be used as guide to the actual relationship. The calculated relationship is weak, accounting for only $12 \%$ of the data assuming that they were normally distributed.

\section{Discussion}

It is standard practice for convenience and efficient use of scarce seed resources in germination studies to estimate viability of the seeds used in a trial (i.e., initial viability) on germinants and viable seeds remaining at the end of the trail. It is assumed that the viability of seeds distributed across treatments at the start is the same, i.e., any sample effects associated with allocating individual seeds to treatments are both random and negligible (this assumption certainly applied to seeds that possessed embryos among the 40 Leucadendron species reported here, Table A1). However, we detected up to a $36 \%$ difference in estimates of mean initial viability between treatments for individual species determined at the end of the trial. We also noted similar marked differences in apparent initial viability between treatments in other studies (Hall et al. [6], Gomez-Gonzalez et al. [7], Figure 1). For one species (L. foedum), even though there was a $22 \%$ difference in the treatment effects on germination, all ungerminated seeds in each treatment at the end of the trial had died on the basis of the cut test. In all cases, this disparity must have arisen during the period that the seeds remained in the different treatments. This means end-of-trial assessment of initial viability can lead to misleading estimates of germination success if it is based on (apparent) initial viability per treatment where this varies markedly between treatments.

The reason is that the treatment itself, especially the control, may unexpectedly cause some seeds to die. In our case, the unanticipated loss of viability during the experiments could not be predicted from the (small) rate of loss of viability during cold storage. On average, the deleterious effect of experimental treatments/controls on viability was an order of magnitude greater than the effect of storage over successive 12 months and had no bearing on the extent to which different treatments affected viability during the trial.

Taking the approach of using germination as the independent variable and viability as the dependent variable, it is evident that, the lower the germination rate, the more likely ungerminated seeds will lose viability during the trial. Thus, it seems that, to some extent (Figure 5), the longer seeds sit in the medium ungerminated, the more likely they will lose viability. That is, the control treatments, where there is little germination response, are most likely to lead to viability loss (Figure 2). Since this relationship only accounted for $12 \%$ of variation in our data for four species, other factors, especially species identity (some species are more vulnerable to viability loss than others), must also contribute to the pattern. At present, we are unable to predict which species are most vulnerable to treatment effects on viability loss, other than to note that soil-stored seeds seem to be particularly susceptible (all species used by Hall et al. [6] and Gomez-Gonzalez et al. [7] were soil-stored), possibly because they may take longer to germinate, and, to a minor extent, species whose maximum viability is not high (here, $L$. corymbosum, L. thymifolium).

A procedural problem is indicated when the controls show lower estimated initial viability than some treatments (e.g., smoke treatment among some soil-stored species in Hall et al. [6], heat treatment of legume seeds in Gomez-Gonzalez et al. [7] - see Figure 1). As a result of these findings, we caution against the routine use of end-of-trial assessment of initial viability in determining germination success of various treatments. Values may prove to have been affected by the experimental design. This could be especially serious where a wide range of treatments may have vastly different effects on estimated viability as we show here for certain species. The problem may be especially difficult to detect when in fact some treatments, e.g., application of fire-type heat, can be expected to cause loss of viability.

Since seed viability loss has a time-dependent component (Ellis and Roberts [18]), if pretrial assessment of initial viability is not practicable, then there is a case for avoiding 
prolonged duration of ungerminated seeds in the treatments. But the answer is not to terminate the trial early, as species vary greatly in their rates of germination; use some other rule, such as terminate if no further germination at twice the interval since the last germination was recorded. Note that terminating the trial at different times between treatments is not a problem as the objective is for all treatments to reach the same stage (start of asymptote) rather than choosing an arbitrary common time when this stage may not have been reached among some slow-germinating treatments. Even so, there was no clear temporal trend among studies in the brief literature survey that we undertook (Table 1). In addition, the best-fit line can be extrapolated back to the diagonal $(X=Y$, Figure 3) and this value (estimated $Y$ ) used for initial viability in calculating germination success. If the figure is substantially $<100 \%$, whether there is a negligible effect of treatment on the level of estimated viability or not, then either a) this represents low viability at the start, or b) the general experimental design has led to a loss of viability. Where a wide range of related species is used and most values approach $100 \%$, as in our case, the latter possibility seems unlikely. As a final but less satisfactory compromise, the treatment that gave the highest viability estimate is used and applied it to all treatments and control (Clarke et al. [5]) that is often near the extrapolated viability value anyway (Figure 3).

The preference is for viability estimates to be undertaken on a separate sample of seeds just before the experimental trial begins, or concurrently with it. This is especially important where pretreatments, e.g, high temperatures, are expected to kill some seeds (Liyanage and Ooi [19]). This means that, to minimize sample effects on pretrial estimates of initial viability, the number of seeds tested need be at least equivalent to the number used in the various treatments. Of course, identifying empty (no embryo), damaged or infested seeds at all stages of the trial is required (Leonard, West and Ojeda [20]), as a separate task from pretrial determination of initial viability of intact seeds. Note that there may be merit in determining the most suitable method for estimating viability before the experiment begins. Thus, Lamont and van Leeuwen [21] showed that there was no difference in estimates of viability of Banksia tricuspis using the cut and tetrazolium tests and thus opted for routine testing with the simpler cut test. It has not been our purpose here to compare different methods of determining seed viability (of which there are many) but we note that sometimes results are based on germinable (imbibed) seeds rather than checking directly for viability (Herranz, Ferrandis and Martínez-Sánchez [22]). However, even imbibed seeds may be nonviable (dead tissues can imbibe), a problem that is exacerbated when there are treatment effects on viability as described here.

It is an interesting final point to consider whether end-of-trial viability should also be estimated to determine if there is an experimental design effect (Liyanage and Ooi [19]. This is important as the ability of the treatment to break dormancy is usually gauged via the level of germination. If final viability is low and treatment independent, it raises the issue whether the general germination conditions imposed are unsuitable for that species, and that other approaches should be considered. Possibilities include using different germination media, such as sand; different incubation temperature regimes; different light and dark exposures, and methods that avoid anoxia due to waterlogging. The method of determining viability may also underestimate levels, e.g., meristematic tissues need to be active for responses to the tetrazolium test (Gosling [1]).

\section{Materials and Methods}

Seeds of 40 Leucadendron species (Table A1) were collected from wild plants in the Western and Eastern Cape Provinces of South Africa and sent to the Millennium Seed Bank at Wakehurst Place in West Sussex, England, and dried to equilibrium at 15\% RH and $18^{\circ} \mathrm{C}$. Nomenclature follows Rebelo (23). Details on the duration of storage are given in Newton et al. (24), doi.org/10.1007/s00442-021-04947-2, Supplementary file1 (DOCX 144 KB). Note that results in that paper were based on filled seeds, not viability/germination at the end of the trial as an estimate of initial viability, as discussed here. Dried seeds were stored at international gene bank standards of $-20^{\circ} \mathrm{C}$ (FAO [25]). Viability of the pre-trial seeds was assessed by the 'cut' test after incubating seeds on $1 \%$ water-agar at 
20/10 ${ }^{\circ} \mathrm{C}$ for 2 weeks: embryos that were white, fully formed and filled the seed cavity were treated as viable and those that were discoloured, shrunken or incompletely formed were treated as nonviable. Binomial mean viabilities at various times during cold storage were calculated.

A fully orthogonal design was used to test the individual and combined effects of direct fire cues (heat and smoke) on postfire germination of 37 species. For three other species, only the combined effect of heat and smoke was examined due to limited seed availability. An after-ripening treatment to simulate exposure to summer temperatures after fire [8 weeks of dry storage at alternating temperatures of $40 / 20^{\circ} \mathrm{C}(12 \mathrm{~h}$ light $/ 12 \mathrm{~h}$ dark)] was applied to all seeds. Seeds in the control treatment received the postfire after-ripening treatment but no heat or smoke. Seeds in the heat treatment and the combined heat plus smoke treatment were heated prior to the postfire after-ripening treatment. Seeds in the smoke only treatment and the combined heat plus smoke treatment received a smoke treatment after the postfire after-ripening treatment.

\subsection{Treatments}

Seeds to receive the heat treatment were divided into five replicate batches of either 50 or 25 seeds per batch for each species and treatment. They were placed in open metal dishes as a monolayer in a fan-assisted, LTE Scientific Incubator with digital temperature control for 20 minutes at $80^{\circ} \mathrm{C}$ (VWR International, Lutterworth, UK). This treatment was chosen to avoid temperatures that might be lethal (Moreira et al. [26]) but simulate the heat from a heathland fire passing over seeds located at a depth of $1 \mathrm{~cm}$. For the smoke treatments, Regen2000® Smokemaster liquid smoke solution (Batch number 11468, Grayson, Australia) was filtered through a sterile $0.2 \mu \mathrm{m}$ Nalgene cellulose acetate $\times 50$ filter syringe (Fisher Scientific, Loughborough, UK) to exclude microbes and large particulates prior to dilution with distilled water (1:10). At the end of the postfire after-ripening temperature period, all seeds were placed in individual Coulter® Counter containers (Scientific Laboratory Supplies, Nottingham, UK). For each species, 10-20 mL of dilute smoke solution (or distilled water) were added to containers. The containers were sealed with polyethylene lids and put into an incubator at $20^{\circ} \mathrm{C}$. After $24 \mathrm{~h}$, seeds were removed from the distilled water or smoke solution and blotted dry. An extra treatment was applied to seven species that were maintained at $25^{\circ} \mathrm{C}(12 \mathrm{~h}$ light $/ 12 \mathrm{~h}$ dark) instead of $40 / 20^{\circ} \mathrm{C}$ that assumed the seeds were not subjected to postfire summer heat before the wet season began.

\subsection{Germination trial}

Following the above pre-treatments, seeds were sown on $1 \%$ water-agar in $90-\mathrm{mm}$ Petri dishes. These were then placed in temperature-controlled incubators set at $20 / 10^{\circ} \mathrm{C}$ (12 h light $12 \mathrm{~h}$ dark). Seeds were scored as germinated and removed once the radicle was longer than $2 \mathrm{~mm}$. Seeds visibly contaminated with fungal mycelium were assumed to be non-viable initially and were removed (negligible in fact), while the remaining seeds were placed on fresh water-agar to prevent fungal spread. Germination tests were terminated if there was no germination in any replicate for at least four weeks. This ensured that the germination level of slow germinating species was not artificially low by terminating the trial before their asymptotes had been reached. Any seeds that had not germinated on completion of the trial were examined for evidence of viability in the same way as when tested during storage. Viability at the onset of the trial (i.e., initial viability) was determined as 100 (germinated seeds + viable seeds remaining at the end of the trial)/(total seeds - empty seeds $=$ filled seeds). Binomial means for initial viability were calculated.

The rate of viability loss (\% per year) during cold storage was determined as (Viability time 2 - Viability time 1)/(time period 1 to 2 in years). Possible treatment effects on initial viability estimates were calculated as (Treatment with highest initial viability Treatment with lowest initial viability) and were compared against treatment effect on filled seeds (Treatment with highest \% filled - Treatment with lowest \% filled). If treat- 
ment effects were random, as they would be for filled seeds at the start of the experiment, then there would be no significant difference in the range between filled and initially viable seeds. If the post-trial estimates of initial viability were significantly different between two treatments, but not between filled seeds, this means that the treatment itself had an effect on viability.

Significant differences in estimated initial viability between treatments, or within filled seeds and initial viability of treatment pairs, were determined by the non-parametric, paired Mann-Whitney test or contingency table analysis, including Fisher's exact test where required (Vassarstats.net, CRichard Lowry 1998-2021), that do not assume normally distributed data. \% germination $(G)$ was plotted against \% initial viability $(\mathrm{V})$ for ten species that showed various levels of treatment effects on estimated initial viability. Independent of treatment, we expect: $G+\Delta V=V$, where $\Delta V$ is the proportion of $\mathrm{V}$ (as a \%) that did not germinate and $\mathrm{V}$ is a constant that should not be affected by the treatment and is usually close to $100 \%$. Although these two variables are not independent ( $\mathrm{G}$ is a component of $\mathrm{V}$ ), we plotted them to a) show visually variations between species in the severity of treatment effects on estimated initial viability, b) determine the rate at which $\mathrm{V}$ can decline with a reduction in $\mathrm{G}$ due to treatment effects via trend lines, and c) as a device for enabling fitted curves to be extrapolated back to the diagonal where $\mathrm{V}=\mathrm{G}$ provides an estimate of 'actual' initial viability. The logarithmic curve fitted most data sets so was used throughout to enable comparisons between species. Since only 4-5 data points, representing binomial means of the different treatments, were available, we were not so interested in the statistical significance of the results as to use them to show the anomalous downward trends in estimated initial viability at lower germination levels among some species when they should have been the same.

Author Contributions: Conceptualization, BBL; methodology, BBL; conduct of experiments, PG.; statistical analyses, tables and figure preparation, BBL; resources, RJN, TH; data curation, PG, RJN, BBL; writing - original draft, BBL; writing - review and editing, RJN, TH; supervision, RJN; project administration, RJN; funding acquisition, RJN, TH. All authors have read and agreed to the published version of the manuscript. Authorship must be limited to those who have contributed substantially to the work reported.

Funding: This work was partly supported by the Australian Research Council (projects DP120013389, DP130103029) and the Bentham-Moxon Trust, Royal Botanic Gardens, Kew, receives grant-in-aid from Defra, UK.

Data Availability Statement: Data supporting this work are given in Appendix Table A1, and Newman et al. (2021), doi.org/10.1007/s00442-021-04947-2, Supplementary file1 (DOCX 144 KB)

Acknowledgments: We thank Ross Turner and SANBI (Kirstenbosch Botanic Garden) for collection of seeds, Richard Cowling for logistic support, Victoria Wilman for early collaboration, Katherine Downes for advice on methodology, Nicola Keogh and John Adams for laboratory support, Berin MacKenzie for statistical advice, Philip Groom for assistance with compiling Table 1, and Alison Powell for comments on the draft manuscript.

Conflicts of Interest: The authors declare no conflict of interest 


\section{Appendix}

Table A1. Location of seeds stored by 40 Leucadendron species, with serial numbers, used in this study plus maximum differences in filled seeds (filled/total) among four treatments, and effect of cold storage and four experimental treatments on their estimated initial viability (viable/filled seeds) estimated with 'cut' test at end of trial. *difference significant at $<5 \%$ with Mann-Whitney test. Max = maximum. Further details in Newman et al. [24], doi.org/10.1007/s00442-021-04947-2, Supplementary file1 (DOCX $144 \mathrm{~KB})$

\begin{tabular}{|c|c|c|c|c|c|}
\hline $\begin{array}{c}\text { Leucadendron } \\
\text { species }\end{array}$ & $\begin{array}{l}\text { Millenium Seed } \\
\text { Bank Serial No. }\end{array}$ & $\begin{array}{l}\text { Stored on } \\
\text { plant } \\
\text { (P) or in soil } \\
\text { (S) }\end{array}$ & $\begin{array}{c}\text { Viability loss } \\
\text { during } \\
\text { cold storage } \\
\text { (\% pa) } \\
\end{array}$ & $\begin{array}{c}\text { Max viability difference } \\
\text { between } 4-5 \text { treatments } \\
\text { estimated at end of } \\
\text { trial (\%) }\end{array}$ & $\begin{array}{c}\text { Max difference in seed } \\
\text { fill between 4-5 } \\
\text { treatments (\%) }\end{array}$ \\
\hline album & 190013 & $P$ & 2.5 & $9.0^{*}$ & 2.4 \\
\hline argenteum & 244145 & $P$ & - & $6.6^{*}$ & 3.2 \\
\hline brunioides & 189761 & S & 2.6 & $14.0 *$ & 2.8 \\
\hline chamalaea & 457752 & $\mathrm{~s}$ & 0.8 & $5.7^{*}$ & 2.8 \\
\hline comosum & 792439 & P & - & $6.9 *$ & 0.8 \\
\hline coniferum & 189185 & $P$ & - & $6.4^{*}$ & 0.0 \\
\hline corymbosum & 214588 & $\mathrm{~s}$ & 0.0 & $35.8^{*}$ & 1.6 \\
\hline discolor & 214810 & P & - & 2.8 & 1.2 \\
\hline dregei & 792440 & P & - & 2.6 & 3.2 \\
\hline elimense & 215068 & S & 0.0 & 4.9 & 1.3 \\
\hline eucalyptifolium & 189679 & P & 0.0 & 2.8 & 0.0 \\
\hline flexuosum & 484101 & $\mathrm{P}$ & - & 1.2 & 2.7 \\
\hline foedum & 486057 & $P$ & - & $20.4^{*}$ & 0.0 \\
\hline galpinii & 214278 & $P$ & - & 3.7 & 4.9 \\
\hline gandogeri & 189521 & $\mathrm{P}$ & 0.0 & 2.8 & 0.0 \\
\hline lanigerum & 214991 & $P$ & - & 3.6 & 1.2 \\
\hline laureolum & 189152 & P & - & $10.0^{*}$ & 0.0 \\
\hline laxum & 215116 & $S$ & 0.0 & $12.7^{*}$ & 1.2 \\
\hline linifolium & 189196 & $P$ & 0.0 & $11.6^{*}$ & 2.0 \\
\hline loranthifolium & 302508 & S & 0.0 & $14.6^{*}$ & 1.2 \\
\hline meridianum & 327170 & $P$ & - & 5.3 & 0.4 \\
\hline microcephalum & 213950 & $\mathrm{P}$ & - & 4.1 & 0.8 \\
\hline modestum & 389697 & $P$ & 0.0 & $9.9 *$ & $5.7^{*}$ \\
\hline muirii & 188672 & $P$ & - & 2.4 & 0.8 \\
\hline nervosum & 792462 & $P$ & - & 3.2 & 1.3 \\
\hline nobilis & 214234 & $P$ & - & 2.8 & 0.0 \\
\hline procerum & 189255 & $P$ & 0.0 & $8.4^{*}$ & 0.0 \\
\hline rourkei & 279394 & P & 0.0 & 2.7 & 0.0 \\
\hline rubrum & 189750 & $P$ & 0.2 & 2.0 & 1.2 \\
\hline salicifolium & 189819 & $P$ & - & 2.0 & 0.0 \\
\hline salignum & 190035 & $P$ & - & 4.0 & 1.8 \\
\hline sericeum & 512228 & $\mathrm{~s}$ & 1.2 & 3.1 & 0.4 \\
\hline spissifolium & 189233 & $P$ & - & $7.6^{*}$ & 1.5 \\
\hline stelligerum & 215091 & $\mathrm{P}$ & - & 4.6 & 0.4 \\
\hline strobilinum & 484042 & $P$ & - & 3.2 & 0.0 \\
\hline teretifolim & 214050 & P & - & 2.8 & 2.0 \\
\hline thymifolium & 792484 & $\mathrm{~s}$ & - & $12.8^{*}$ & $10.2^{*}$ \\
\hline tinctum & 160283 & $S$ & 0.0 & 1.2 & 0.0 \\
\hline uliginosum & 189222 & P & 0.0 & $5.9 *$ & 1.6 \\
\hline
\end{tabular}




\begin{tabular}{|c|c|c|c|c|}
\hline xanthoconus & 189141 & - & 3.4 & 0.0 \\
\hline & Overall mean for all species & 0.4 & 6.7 & 1.4 \\
\hline & Mean for 17 species in common & 0.4 & 8.7 & 1.5 \\
\hline
\end{tabular}

\section{References}

1. Gosling, P.G. Chapter 24: Viability testing. In Seed Conservation: Turning Science into Practice. Pritchard, H.W., Probert, R.J., Eds.; The Royal Botanic Gardens, Kew, UK. 2003; pp. 445-481.

2. Williams, I.J.M. A revision of the genus Leucadendron (Proteaceae). Contrib. Bolus Herb. 1972, 3, 1-425.

3. Tonnabel, J.; Schurr, F.M.; Boucher, F.; Thuiller, W.; Renaud, J.; Douzery, J.P.; Ronce, O. Life-history traits evolved jointly with climatic niche and disturbance regime in the genus Leucadendron (Proteaceae). Amer. Nat. 2018, 91, $220-234$.

4. Hay, F.R.; Probert, R.J. 2013, Advances in seed conservation of wild plant species: a review of recent research. Conserv. Physiol. 2013, 1, cot030. doi:10.1093/conphys/cot030.

5. Clarke, P.J., Davison E.A., Fulloon L. Germination and dormancy of grassy woodland and forest species: effects of smoke, heat, darkness and cold. Aust. J. Bot. 2000, 48, 697-700.

6. Hall, S.A., Newton, R.J., Holmes, P.M., Gaertner, M. and Esler, K.J. Heat and smoke pre-treatment of seeds to improve restoration of an endangered Mediterranean climate vegetation type. Austral Ecol. 2017, 42, 354-366.

7. Gómez-González, S.; Paula, S.; Cavieres, L.A.; Pausas, J.G Postfire responses of the woody flora of Central Chile: insights from a germination experiment. PLOS ONE 2017, 12, e0180661. https://doi.org/10.1371/journal.pone.0180661

8. Collette, J.C.; Ooi, M.K.J. Germination ecology of the endangered species Asterolasia buxifolia (Rutaceae): smoke response depends on season and light. Aust. J. Bot. 2017, 65, 283-291.

9. Crosti, R.; Ladd, P.G.; Dixon K.W.; Piotto, B. Post-fire germination: The effect of smoke on seeds of selected species from the central Mediterranean basin. For. Ecol. Manage. 2006, 221, 306-312.

10. Daibes, L.F.; Pausas, J.G.; Bonani, N.; Nunes, J.; Silveira, F.A.O.; Fidelis, A. Fire and legume germination in a tropical savanna: ecological and historical factors. Ann. Bot. 2019, 123, 1219-1229. doi:10.1093/aob/mcz028

11. Dayamba, S.D.; Tigabu, M.; Sawadogo, L.; Oden, P.C. Seed germination of herbaceous and woody species of the Sudanian savanna-woodland in response to heat shock and smoke. For. Ecol. Manage. 2008, 256, 462-470.

12. Fernandes, A.F.; Oki, Y.; Fernandes, G.W.; Moreira, B. The effect of fire on the seed germination of campo rupestre species in the South American Cerrado. Plant Ecol. 2020, 222, 45-55.

13. Hodges, J.A.; Price, J.N.; Nimmo, D.G.; Guja, L.K. Evidence for direct effects of fire-cues on germination of some perennial forbs common in grassy ecosystems. Austral Ecol. 2019, 44, 1271-1284.

14. Jeffrey, D.J.; Holmes, P.M.; Rebelo, A.G. Effects of dry heat on seed germination in selected indigenous and alien legume species in South Africa. S. Afri. J. Bot. 1988, 54, 28-34.

15. Liyanage, G.S.; Offord, C.A.; Sommerville, K.D. Techniques for breaking seed dormancy of rainforest species from genus Acronychia. Seed Sci. Tech. 2020, 48, 159-165. doi:10.15258/sst.2020.48.2.03

16. Overbeck, G.E.; Müller, S.C.; Pillar, V.D.; Pfadenhauer, J. No heat-stimulated germination found in herbaceous species from burned subtropical grassland. Plant Ecol. 2006, 184, 237-243.

17. Shayanfar, A.; Ghaderi-Far, F.; Behmaram, R.; Soltani A.; Sadeghipour, H.R. Impacts of fire cues on germination of Brassica napus L. seeds with high and low secondary dormancy. Plant Biol. 2020, 22, 647-65417.

18. Ellis, R.H.; Roberts, E.H. Improved equations for the prediction of seed longevity. Ann. Bot. 1980, 45, 13-30.18.

19. Liyanage, G.S.; Ooi, M.K. Seed size-mediated dormancy thresholds: a case for the selective pressure of fire on physically dormant species. Biol. J. Linn. Soc. 2017, 123, 135-143.

20. Leonard, J.; West, A.G.; Ojeda, F. Differences in germination response to smoke and temperature cues in 'pyrophyte'and 'pyrofuge' forms of Erica coccinea (Ericaceae). Internat. J. Wildl. Fire 2018, 27, 562-568.

21. Lamont, B.B.; van Leeuwen, S.J. Seed production and mortality in a rare Banksia species. J. Appl. Ecol. 1988, 25, 551-559.24.

22. Herranz, J.M.; Ferrandis, P.; Martínez-Sánchez, J.J. Influence of heat on seed germination of nine woody Cistaceae species. Internat. J. Wildl. Fire 1999, 9, 173-182.

23. Rebelo, T. Proteas: a field guide to the proteas of Southern Africa, 2nd ed. Fernwood Press, Cape Town, S Africa. 2001.

24. Newton, R.J.; Mackenzie, B.D.E.; Lamont, B.B.; Gomez-Barreiro, P.; Cowling, R.M.; He, T. Fire-mediated germination syndromes in Leucadendron (Proteaceae) and their ecological correlates. Oecologia 2021, 196, 589-604. doi.org/10.1007/s00442-021-04947-2

25. FAO (2014) Genebank standards for plant genetic resources for food and agriculture, revised ed. FAO, Rome, Italy.

26. Moreira, B.; Tormo, J.; Estrelles, E.; Pausas, J.G. Disentangling the role of heat and smoke as germination cues in Mediterranean Basin flora. Ann. Bot. 2010, 105, 627-635. 